\title{
Analisis Pemetaan Model Bisnis Platform Online Property di Indonesia dengan Menggunakan Platform Design Toolkit
}

\author{
Nuzulia Rachma dan Arif Wibisono \\ Departemen Sistem Informasi, Fakultas Teknologi Informasi, Institut Teknologi Sepuluh Nopember (ITS) \\ e-mail: erma@its.sby.edu
}

\begin{abstract}
Abstrak-Pertumbuhan Ekonomi Indonesia kuartal kedua tahun 2016 menunjukkan tren yang positif. Berdasarkan data dari Badan Pusat Statistik (BPS) angka pertumbuhan Produk Domestik Bruto (PDB) meningkat sebesar 5,18 persen tahun ke tahun. Secara nilai, Produk Domestik Bruto (PDB) kuartal II tahun 2016 mencapai Rp2.353,2 triliun dan berdasarkan ADHB (Atas Dasar Harga Berlaku) mencapai Rp3.086,6 triliun. Berkaitan dengan sektor properti, optimisme perkembangan industri di sektor ini pun dinilai cukup baik, hal ini dapat terlihat dari angka penanam modal yang dilakukan oleh investor asing yang pada tahun 2016 kuartal II mencapai Rp151,6 triliun lebih tinggi sekitar 12,3 persen jika dibandingkan dengan kuartal yang sama di tahun 2015. Kendati memiliki optimisme yang tinggi, ternyata tingkat penyerapan properti pada beberapa jenis properti tidak semuanya berjalan dengan baik. ada beberapa jenis properti yang justru kurang diminati bahkan ada beberapa yang mencapai titik terendah. Contohnya seperti sektor perkantoran, permintaan sewa kantor di wilayah Central Business District (CBD) Jakarta mengalami penurunan permintaan, tercatat sepanjang kuartal II 2016 permintaan sewa kantor menjadi 85,6 persen, jika dibandingkan dengan periode yang sama di tahun sebelumnya yang mencapai 93,7 persen. Begitu juga untuk di sektor apartemen, permintaan akan hunian vertikal tersebut masih belum menujukkan gairah yang positif, tercatat sepanjang kuartal II tahun 2016 pertumbuhan permintaaan akan apartemen hanya tumbuh dibawah satu persen jika dibandingkan dengan kuartal sebelumnya di tahun yang sama . Menurunnya permintaan ini, akhirnya membuat harga apartemen menjadi melambat, tercatat saat ini harga apartemen hanya tumbuh sebesar 4,6 persen pada kuartal III. Disisi lain, penggunaan internet yang semakin tinggi di Indonesia, membawa dampak tersendiri bagi perkemangan industry property. Kemudahan mengakses informasi semakin di rasakan oleh masyarakat. Hal ini dimanfaatkan oleh beberapa orang yang memang jeli mengetahui peluang ini. Dari peluang tersebut, muncul-lah platform online property. Pada penelitian kali ini akan membahas bisnis model yang dimiliki oleh suatu online property. Nilai apa saja yang diberikan dari platform online property bagi penggunanya.
\end{abstract}

Kata Kunci-Online Property, Real-Estate, Platform Online Properrty.

\section{PENDAHULUAN}

$\mathrm{M}$ ENURUT data dari Badan Koordinasi Penanaman Modal (BPKM), Penanaman Modal Dalam Negeri
(PMDN) dan Penanaman Modal Asing (PMA) triwulan pertama meningkat $13,8 \%$ dibandingkan dengan triwulan yang sama tahun 2016. Capaian realisasi investasi triwulan pertama 2017 ini menggambarkan minat investasi di Indonesia masih tetap tinggi [1].

Data menunjukkan bahwa minat investasi memang masih tinggi, namun lain halnya jika dilihat dari sektor properti, ada beberapa jenis properti yang justru kurang diminati. Seperti contohnya ialah permintaan hunian vertikal (apartemen) yang belum menunjukkan indikasi positif. Hal tersebut sesuai dengan catatan pada kuartal ke II tahun 2016 bahwa pertumbuhan permintaan apartemen tumbuh dibawah $1 \%$ jika di bandingan di kuartal I tahun 2016 [2].

Dilain sisi, pertumbuhan internet di dunia terus berkembang. Hasil analisa statistik bulan Januari 2017 menunjukkan dari 7.476 juta total populasi di dunia, 3.773 juta merupakan pengguna internet aktif. Angka tersebut meningkat 10\% dari tahun 2016 [3] Dengan melemahnya sektor properti di Indonesia, dan tinggi nya pertumbuhan Internet di Indonesia, menjadikan wadah baru bagi para investor yang jeli melihat peluang ini. Peluang ini dimanfaatkan oleh para investor yaitu dengan membuat platform online untuk meningkatkan penjualan properti. Dengan adanya platform online property ini, diharapkan dapat mempertemukan penjual dan pencari property, sehingga dapat menaikkan penjualan properti.

Di Indonesia, sudah terdapat berbagai macam platform online property yang menjalankan bisnisnya. Setiap platform memiliki keunggulan masing-masing, dan memberikan nilai tersendiri bagi penggunanya. Namun, hingga saat ini, masih belum ada penelitian yang membahas dan memetakan model bisnis seperti apa yang digunakan oleh platform online property.

Fokus dari penelitian ini ialah memetakan model bisnis yang digunaan suatu platform online property di Indonesia. Penelitian ini dapat digunakan utnuk mengetahui siapakah orientasi dari suatu platform online property. Selain itu penelitian ini juga dapat digunakan oleh pemilik platform online property untuk mengetahui nilai tambah apa yang harus diberikan dari suatu platform agar menarik minat pemasar. Sebelumnya belum ada penelitian yang membahas pemetaan model bisnis pada platform online property. Penelitian lain mengenai platform online property adalah memodelkan dan mensimulasikan informasi pintar pada platform online property[4] Dari pencarian penelitian terdahulu, belum ada yang membahas mengenai bagaimana model bisnis yang digunakan suatu platform online property dan orientasi dari suatu platform online property. 
Analisis dan perbandingan penelitian ini menggunakan pemodelan bisnis Platform Design Toolkit. Platform Design Toolkit ini mempunyai 9 perspektif yang dapat memudahkan dalam penelitian. Perspektif tersebut ialah Platform owner, platform stakeholder, Peers, Partners, Channel and Context, Transaction, Service, Value Propositions, Infrastructure and Core Components [5]

Penulis menggunakan framework ini dikarenakan framework ini dapat memetakan komponen-komponen model bisnis di dalam sebuah platform online property. Dari hasil pemetaan komponen- komponen yang sudah disebutkan, maka akan dapat dibandingkan antara satu platfrom dengan platform lainnya. Dengan menggunakan framework platform design toolkit, akan dapat dilihat siapakah orientasi dari masing-masing platform online property, lebih terhadap partner, consumer, atau producer. Selain itu juga dapat melihat value yang di tawarkan oleh masing-masing platform online property.

\section{DASAR TEORI}

\section{A. Platform}

Platform merupakan struktur tata kelola yang dapat menentukan aktor siapa saja yang berpartisipasi, peran aktor yang dimainkan, bagaimana cara setaip aktor berinteraksi, dan bagaimana menyelesaikan masalah dan untuk memfasilitasi hubungan, koordinasi dan kolaborasi[6]

Dalam penelitian ini, platform merupakan sebuah model bisnis yang menjadikan producers dan consumers dapat berinteraksi dengan sebuah infrastuktur yang dapat menjembatani hubungan antar keduanya[7]

\section{B. Platform Design Toolkit}

Platform Design Toolkit merupakan hasil modifikasi dari Business Model Canvas buatan Alexander Ostwalder yang dilakukan oleh Simon Cirero pada tahun 2013. Modifikasi ini dilakukan karena Business Model Canvas dirasa terlalu luas dalam menjabarkan suatu model bisnis. Platform Design Toolkit ini dapat digunakan oleh beberapa pengguna, seperti corporate intrapreneur yang ingin menaklukkan pasar dan merancang organisasi agar menjadi lebih baik. Pengguna selanjutnya ialah pendiri start up yang ingin mengetahui model bisnis yang akan dibangun. Selain itu, dapat digunakan bagi para konsultan untuk membantu inovasi desain klien dan yang terakhir ialah bagi siapa pun yang ingin memahami bagaimna platform bekerja. Tujuan dari Platform Design Toolkit ialah sebagai bahasa yang mendeskripsikan dan memanipulasi model supaya dapat memikirkan alternatif strategi untuk suatu platform. Platform Design Toolkit Platform Design Toolkit memiliki 9 perspektif antara lain:

a. Platform Owner

Perspektif ini memiliki entitas yang mempunyai tanggung jawab dan visi atas adanya platform yang terealisasi di pasar dan juga bertanggungjawab atas keberadaan platform tersebut. Biasanya, entitas ini berisi organisasi non-profit, foundation ataupun organisasi yang ters truktur.

b. Platform Stakeholder

Platform Stakeholder berisi entitas yang mengatur hasil dari platform dan hubungan platform dengan eksternal. Berisi pula entitas yang memiliki kepentingan tertentu dalam kegagalan maupun kesuksesan platform. Entitas yang berada di perspektif ini biasanya terkena dampak secara langsung dari platform baik dampak positif maupun dampak negatif.

c. Peers

Pada perspektif ini berisi entitas yang memiliki tujuan khusus dengan value proposition dari sebuah platform. Dalam perspektif ini, dikategorikan 2 macam yang termasuk peers, yaitu peers consumer dan peers producers. Peers Producers : memiliki entitas yang menambahkan atau menciptakan value bersama dengan sebuah platform. Biasanya entitas ini akan mencari kesempatan untuk meningkatkan profesionalitas. Peers Consumer : memiliki entitas yang tertarik dalam menggunakan, mengonsumsi, dan memanfaatkan value dari sebuah platform.

\section{d. Partners}

Pada prespektif ini berisi entitas yang profesional, sehingga dapat menciptakan value yang lebih maksimal untu suatu platform.

e. Channel and Context

Pada perspektif ini, merupakan tempat dilakukannya pertukaran dan bagaimana penyampaian value ke peers consumer. Dalam menyampaikan value terdapat dua cara yaitu dengan cara yang sudah didesain (channel) dan yang kedua ialah cara informal (context).

\section{f. Transaction}

Perspektif ini merupakan kegiatan bertukar atau pemindahan antara peers ataupun partners. Aktivitas tersebut dapat dilakukan aabila terdapat nilai yang dibuat, disediakan, ataupun ditransfer antara satu entitas dengan entitas lain.

\section{g. Services}

Perspektif ini berisi layanan yang berguna untuk mengembangkan pengguna dalam menikmati platform. Terdapat 3 services, yaitu enabling services yang membantu partners dalam menghasilkan value. Empowering services yang membantu peers producer melakukan transaksi. Serta yang terakhir ialah Other Services yang menjadi pelengkap saat value tersampaikan.

h. Value Proposition

Pada perspektif ini berisi tentang paket produk atau layanan yang akan diberikan kepada peers. Ada 2 jenis value proposition, yaitu core value propositions yang merupakan value utama dari sebuah platform. Tujuan utama dari adanya platform tersebut terdapat didalam value proposition. Jenis kedua ialah ancillary value proposition yang merupakan value sekunder dari sebuah platform. Core value proposition biasanya tertuju pada peer consumer, sedangkan untuk ancillary value proposition tertuju pada peer producers.

\section{i. Infrastucture and Core Component}

Pada perspektif ini, berisikan aset yang dikelola dan dimiliki oleh platforms owners. Aset dapat berupa tangible (dapat diukur) dan intangible (tidak dapat diukur). Aset yang dikelola ini, memastikan bahwa platform berjalan dengan baik dan dapat dipakai oleh ecosystem.

\section{METODOLOGI}

\section{A. Studi Literatur}

Tahapan awal yang dilakukan ialah mencari studi literatur mengenai platform online properti yang ada di Indonesia. 


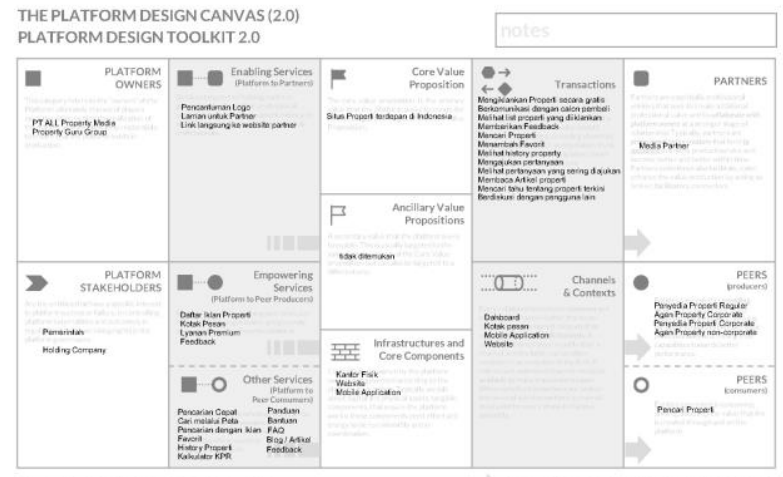

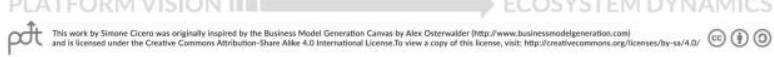

Gambar 1. Platform Design Canvas Rumah.

THEPLATFORM DESIGN CANVAS (2.0) PLATFORM DESIGNTOOLKIT 20

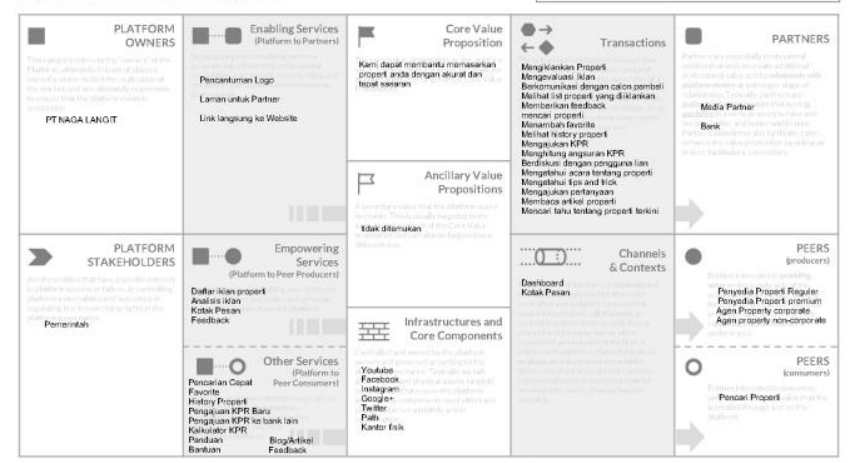

PLATFORM VISION IIIIIIC

Gambar 2 Platform Design Canvas Rumahku.

THEPLATFORM DESIGN CANVAS (2.0) PLATFORM DESIGN TOOLKIT 2.0

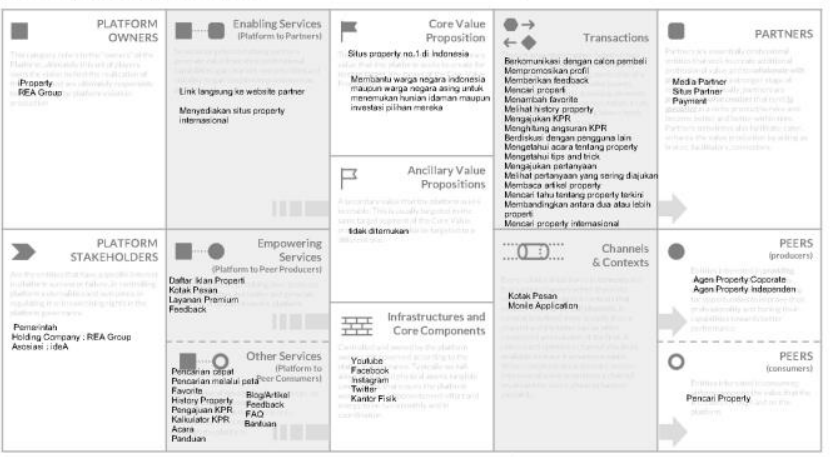

SLATFORM VISION IIU⿴囗十 ECOSYSTEM DYNAMICS

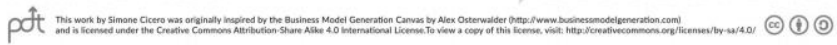

Gambar 3 Platform Design Canvas Rumah123.

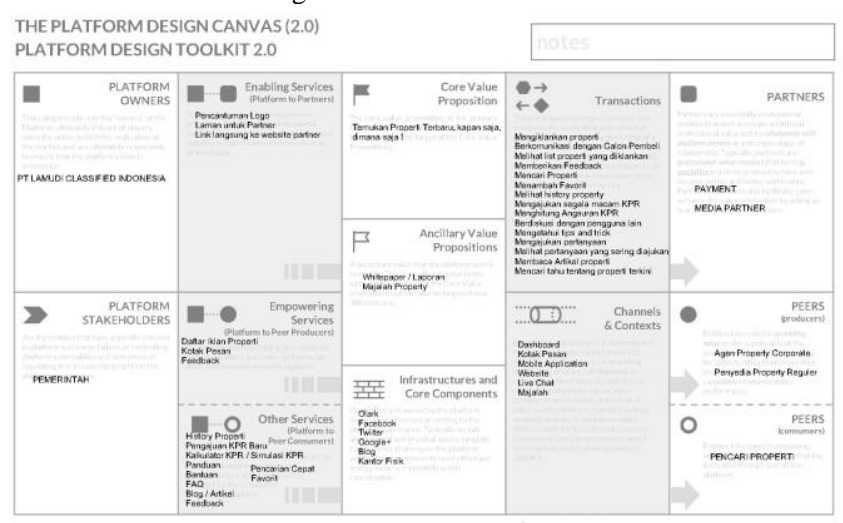

PLATFORM VISION IIIIER $\rightarrow$ ECOSYSTEM DYNAMICS

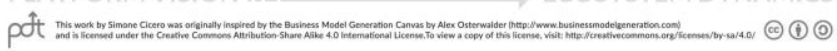

Gambar 4 Platform Design Cnvas Lamudi.

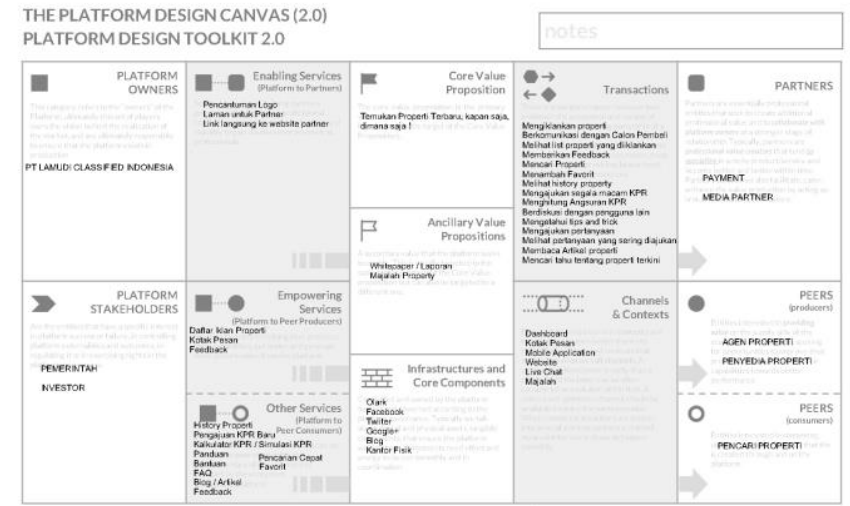

PLATFORM VISION IIUIL $\longrightarrow$ ECOSYSTEM DYNAMICS

Gambar 5 Platform Design Canvas UrbanIndo.

THE PLATFORM DESIGN CANVAS (2.0) PLATFORM DESIGN TOOLKIT 20

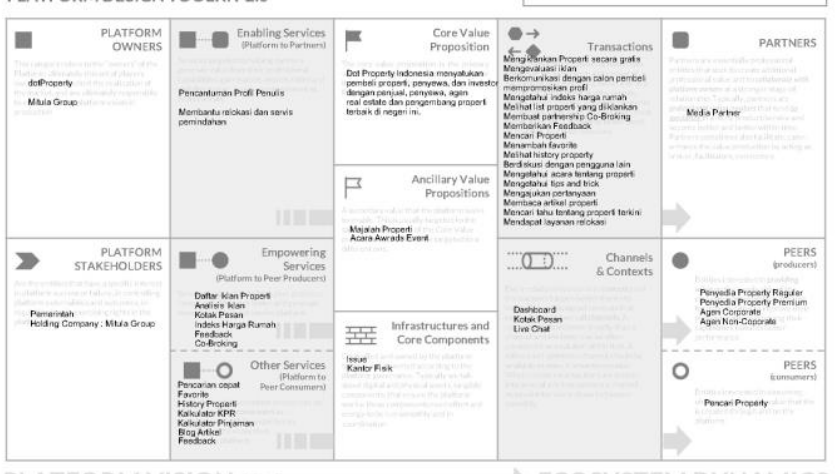

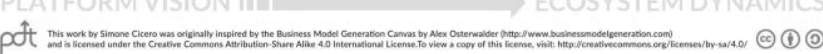

Gambar 6 Platform Design Canvas dotProperty.

Literatur disini adalah penjelasan konsep-konsep atau penelitian terdahulu yang pernah dilakukan terkait permasalahan. Literatur dapat berasal dari dokumentasi dalam bentuk buku, jurnal, maupun website. Pada tahap ini, menghasilkan pemahaman mengenai definisi dan teori terkait dengan Platform online properti, serta penelitian-penelitian yang pernah dilakukan sebelumnya mengenai Platform online properti.

\section{B. Metode Pemilihan Platform Online Property}

Dalam tahap ini, ditentukan metode untuk pemilihan Platform online properti. Metode ini bertujuan untuk menentukan Platform online property yang akan diteliti dan digunakan dalam tugas akhir. Dalam pemilihan Platform online properti dilakukan dengan cara, melihat platform yang memiliki kemiripan dalam hal online property, yang ada di Alexa.com. Hasil dari tahapan ini berupa 9 platform online property..

\section{Identifikasi Platform Online Property}

Pada tahap ini, akan dilakukan identifikasi dari kesembilan platform online properti yang ingin dibandingkan. Hal yang akan diidentifikasi antara lain ialah peringkat setiap platform, fasilitas yang diberikan dari setiap platform, dan lain-lain. Tahap identifikasi ini dilakukan dengan cara melakukan observasi aktif dan pasif, melihat web review, dan mencari white paper. Dengan hasil identifikasi yang sudah didapatkan, penulis dapat melakukan analisis dan perbandingan yang akan menjawab permasalah. 
Tabel 2.

Pemetaan Platform Owners

\begin{tabular}{|c|c|c|c|c|c|c|}
\hline \multirow{2}{*}{ Grouping } & \multicolumn{6}{|c|}{ Platform } \\
\hline & RK & $\mathrm{U}$ & LI & $\mathrm{R}$ & Rl23 & DP \\
\hline $\begin{array}{l}\text { Jenis } \\
\text { Perusahaan }\end{array}$ & $\begin{array}{l}\text { Perseroan } \\
\text { Terbatas }\end{array}$ & $\begin{array}{l}\text { Perseroan } \\
\text { Terbatas }\end{array}$ & $\begin{array}{l}\text { Perseroan } \\
\text { Terbatas } \\
\end{array}$ & $\begin{array}{l}\text { Perseroan } \\
\text { Terbatas }\end{array}$ & $\begin{array}{l}\text { Tidalk } \\
\text { ditemukan }\end{array}$ & $\begin{array}{l}\text { Company } \\
\text { Group }\end{array}$ \\
\hline $\begin{array}{l}\text { Bahasa di } \\
\text { Web }\end{array}$ & Indonesia & $\begin{array}{l}\text { Indonesia, } \\
\text { Ingrris }\end{array}$ & $\begin{array}{l}\text { Indonesia, } \\
\text { Ingris }\end{array}$ & Indonesia & $\begin{array}{l}\text { Indonesia, } \\
\text { Inggris }\end{array}$ & $\begin{array}{l}\text { Indonesia, } \\
\text { Inggris }\end{array}$ \\
\hline (Kantor Fisik) & \begin{tabular}{|l|} 
Jakarta \\
\end{tabular} & Bandung & Jakarta & Jakarta & Jakarta & Jakarta \\
\hline Status & Altif & Aktif & Aktif & Aktif & Antif & Aktif \\
\hline $\begin{array}{l}\text { Kepemilikan } \\
\text { Perusahaan } \\
\text { dalam Negeri }\end{array}$ & $\begin{array}{l}\text { PT Naga } \\
\text { Langit }\end{array}$ & $\begin{array}{l}\text { PT Kreasi } \\
\text { Anak } \\
\text { Bangsa }\end{array}$ & $\begin{array}{l}\text { PT Lamudi } \\
\text { Classifieds } \\
\text { Indonesia }\end{array}$ & $\begin{array}{l}\text { PT All } \\
\text { Property } \\
\text { Media }\end{array}$ & Rumah123 & $\begin{array}{l}\text { DotProperty } \\
\text { Indonesia }\end{array}$ \\
\hline $\begin{array}{l}\text { Kepemilikan } \\
\text { Perusahaan } \\
\text { Luar Negeri }\end{array}$ & - & - & \begin{tabular}{|l|} 
Venture \\
Rocket \\
Internet \\
\end{tabular} & $\begin{array}{l}\text { Property } \\
\text { Guru Group }\end{array}$ & $\begin{array}{l}\text { IProperts } \\
\text { Group dan } \\
\text { REA Group }\end{array}$ & $\begin{array}{l}\text { Mitulala } \\
\text { Group }\end{array}$ \\
\hline Tahun Berdiri & 2011 & 2011 & 2013 & 2015 & 2007 & 2016 \\
\hline $\begin{array}{l}\text { Usia Platform } \\
\text { beroperassi di } \\
\text { Indonesia }\end{array}$ & 6 Tahun & 6 Tahun & 4 Tahun & 2 tahun & 10 tahun & 1 tahun \\
\hline $\begin{array}{l}\text { Total iklan } \\
\text { alktif }\end{array}$ & 220576 & 1.225 .866 & 263112 & 448,243 & - & 52,316 \\
\hline $\begin{array}{l}\text { Jumlah Agen } \\
\text { Terdaftar }\end{array}$ & 13000 & 73.369 & - & 7829 & $\begin{array}{l}\text { Kurang } \\
\text { lebih } 10.000\end{array}$ & $\begin{array}{l}\text { Kurang } \\
\text { lebih 586 }\end{array}$ \\
\hline Tine Bisnis & Start-Up & Start-Up & Start-Up & Start-Up & Start-Up & Start-Up \\
\hline Area Served & Indonesia & Indonesia & Indonesia & $\begin{array}{l}\text { Indonesia } \\
\text { gan } \\
\text { Internasional }\end{array}$ & $\begin{array}{l}\text { Indonesia } \\
\text { gan } \\
\text { Internasional }\end{array}$ & $\begin{array}{l}\text { Indonesia } \\
\text { dan } \\
\text { Internasional }\end{array}$ \\
\hline $\begin{array}{l}\text { Peringkat } \\
\text { Alexa } \\
\text { Indonesia }\end{array}$ & 3.891 & 890 & 1.830 & 741 & 869 & 7,915 \\
\hline $\begin{array}{l}\text { Peringkat } \\
\text { Alexa Global }\end{array}$ & 211.714 & 56.353 & 88.872 & 45,738 & 45.079 & 449,471 \\
\hline
\end{tabular}

\section{Persiapan Instrumentasi dan Pengambilan Data}

Pada tahap ini, akan dilakukan persiapan dalam melakukan pengambilan data. Pengambilan data berupa kuisioner, materi interview dengan narasumber, studi dokumen, dan lain-lain. Hasil dari tahapan ini, ialah perangkat-perangkat yang digunakan dalam pengambilan data.

\section{E. Pengambilan Data}

Pada tahap ini, akan dilaukan pencarian data yang belum ditemukan dalam tahap identifikasi Platform Online Properti. Data yang dicari, akan mengacu pada Platform Design Toolkit. Dengan data-data yang telah didapatkan tersebut, langkah selanjutnya ialah memetakan dalam platform design toolkit.

\section{F. Pemetaan Hasil Pengambilan Data dengan Platform Design Tookit}

Dari hasil tahap sebelumnya, yaitu pengambilan data, tahap selanjutnya ialah memetakan hasil dari masing-masing platform online property ke dalam platform design toolkit. Hasil pemetaan dari platform design toolkit akan dianalisa dan dibandingkan untuk menjawab permasalahan yang telah ditentukan sebelumnya.

\section{G. Analisis Hasil Pemetaan dan Perbandingan Model}

Tahap ini merupakan tahapan dalam menyusun platform design toolkit dari masing-masing platform online property menggunakan data-data yang telah didapatkan dari tahap sebelumnya. Analisis dilakukan dengan cara membandingkan dari data-data yang sudah didapatkan beserta model bisnisnya. Dengan melakukan tahap analisis ini diharapkan akan mendapatkan kesimpulan dan solusi untuk menyelesaikan permasalahan.

\section{H. Analisis Hasil Pemetaan dan Perbandingan Model}

Tahap ini merupakan tahap yang menjadi hasil dari penelitian. Pada tahap ini, dilakukan pembuatan kesimpulan dari hasil analisis. Melalui kesimpulan tersebut, akan
Tabel 1.

Pemetaan Platform Stakeholder.

\begin{tabular}{|c|c|c|c|c|c|c|}
\hline \multirow{2}{*}{ Grouping } & \multicolumn{6}{|c|}{ Platform } \\
\hline & LI & $\mathbf{R}$ & RK & DP & $\mathrm{U}$ & R123 \\
\hline Regulator & $\begin{array}{l}\text { Pemerintah } \\
\text { Indonesia }\end{array}$ & $\begin{array}{l}\text { Pemerintah } \\
\text { Indonesia }\end{array}$ & \begin{tabular}{|l|} 
Pemerintah \\
Indonesia \\
\end{tabular} & $\begin{array}{l}\text { Pemerintah } \\
\text { Indonesia }\end{array}$ & $\begin{array}{l}\text { Pemerintah } \\
\text { Indonesia } \\
\end{array}$ & $\begin{array}{l}\text { Pemerintah } \\
\text { Indonesia }\end{array}$ \\
\hline Holding Company & Lamudi Ltd & $\begin{array}{l}\text { Property } \\
\text { Guru } \\
\text { Group }\end{array}$ & - & $\begin{array}{l}\text { Mitula } \\
\text { Group }\end{array}$ & 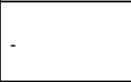 & $\begin{array}{l}\text { REA } \\
\text { Group Ltd }\end{array}$ \\
\hline $\begin{array}{l}\text { Investor Dalam } \\
\text { Negeri }\end{array}$ & Tidak Ada & Tidala Ada & - & Tidala Ada & Tidalat Ada & Tidak ada \\
\hline $\begin{array}{l}\text { Investor Luar. } \\
\text { Negeri }\end{array}$ & - & - & - & - & $\begin{array}{l}\text { East Ventures, } \\
\text { Gree Ventures, } \\
\text { Fenox Ventures, } \\
\text { Spiral Ventures }\end{array}$ & - \\
\hline $\begin{array}{l}\text { Jumlah Lead } \\
\text { Investor }\end{array}$ & - & - & - & - & 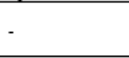 & - \\
\hline Jumlah Investor & - & - & - & - & - & - \\
\hline Total Investasi & - & - & - & - & $\$ 2,000,000$ & - \\
\hline Status Funding & - & - & - & - & $\begin{array}{l}\text { Early Stage } \\
\text { Venture } \\
\end{array}$ & - \\
\hline $\begin{array}{l}\text { Tipe Funding } \\
\text { terbaru }\end{array}$ & - & - & - & - & Series A & - \\
\hline Komunitas Penjual & - & - & - & - & Ada & - \\
\hline Komunitas Pembeli & - & - & - & - & Ada & - \\
\hline $\begin{array}{l}\text { Assosiassi Online } \\
\text { Property }\end{array}$ & - & - & - & - & - & ideal \\
\hline
\end{tabular}

didapatkan teori mengenai perbandingan keunggulan antara satu platform online property satu dengan platform online property lainnya yang dilihat dari sudut pandang platform design toolkit.

\section{MODEL DAN IMPLEMENTASI}

\section{A. Identifikasi Platform Online Property}

Pada sub-bab ini, berisi Platform Online Property yang digunakan untuk penelitian. Untuk mengidentifikasi platform online property yang digunakan, penulis menggunakan ranking pada Alexa Web Series. Angka ranking yang diambil ialah angka ranking dunia dan di Indonesia. Angka peringkat tersebut didapatkan dari rata-rata pengunjung website tersebut dalam satu hari. Sehingga, apabila angka peringkat suatu platform, maka semakin tinggi pula popularitas dari platform tersebut.

\section{B. Pengambilan Data}

Peneliti mengirimkan permintaan untuk melakukan observasi dan wawancara mengenai platform untuk mendapatkan informasi mengenai perspektif yang ada di dalam Platform Design Toolkit. Namun, semua platform tidak merespon dalam memberikan informasi tersebut, sehingga peneliti melakukan observasi secara langsung dan tidak langsung.

Observasi secara langsung dilakukan dengan cara menggunakan platform dari mendaftar hingga mencoba layanan-layanan yang diberikan oleh platform. Observasi tidak langsung dilakukan dengan cara mencari informasi pada halaman-halaman berita yang berkaitan dengan platform. (Gambar 1-6)

\section{PEMETAAN DAN ANALISIS HASIL}

Setelah mendapatkan informasi-informasi terkait platform, peneliti mengkategorikan informasi-informasi tersebut berdasarkan Platform Design Toolkit. Lalu dilakukan pemetaan berdasarkan kategor yang ada. Dari hasil ini, didapatkan peta model bisnis dan platform online property dari kategori-kategori berdasarkan Platform Design Toolkit. (Tabel 1-6) 
Tabel 3.

Pemetaan The Partner

\begin{tabular}{|c|c|c|c|c|c|c|}
\hline Grouping & \multicolumn{6}{|c|}{ Platform } \\
\hline Payment & $\mathrm{DP}$ & $\mathrm{R}$ & RK & R123 & LI & $\mathrm{U}$ \\
\hline KPR/Cicilan & - & - & $\begin{array}{l}\text { KPR } \\
\text { BTN }\end{array}$ & $\begin{array}{l}\text { KPR Mandiri, } \\
\text { KPR BNI, } \\
\text { KPR BRI, } \\
\text { KPR BCA, } \\
\text { gan KPR } \\
\text { BTN }\end{array}$ & $\begin{array}{l}\text { KPR } \\
\text { Mandirit } \\
\text { dan } \\
\text { KPR } \\
\text { BCA }\end{array}$ & $\begin{array}{l}\text { DBS, } \\
\text { Maybank, } \\
\text { Bank } \\
\text { Muamalat, } \\
\text { CIMB Niaga, } \\
\text { BFI, Panin } \\
\text { Dubai } \\
\end{array}$ \\
\hline Visa & - & - & - & Ada & - & Ada \\
\hline Master Card & - & - & - & - & - & Ada \\
\hline Media Transfer & - & - & - & - & - & Ada \\
\hline Doku & - & - & - & - & - & Ada \\
\hline Virtual Account & - & - & - & - & - & Ada \\
\hline \multicolumn{7}{|l|}{ Media Partner } \\
\hline Online News & Ada & $\mathrm{Ada}$ & $\mathrm{Ada}$ & Ada & Ada & Ada \\
\hline Blog/Jurnal/Artikel & Ada & Ada & Ada & Ada & Ada & Ada \\
\hline
\end{tabular}

Tabel 4.

Pemetaan The Peers

\begin{tabular}{|l|l|l|c|c|c|c|c|}
\hline \multicolumn{2}{|c|}{ Grouping } & \multicolumn{6}{|c|}{ Platform } \\
\hline Peer producers & Rl23 & LI & DP & U & RK & R \\
\hline & Agen Corporate & Ada & Ada & Ada & Ada & Ada & Ada \\
\hline & $\begin{array}{l}\text { Agen Non- } \\
\text { Corporate }\end{array}$ & Ada & - & Ada & Ada & Ada & Ada \\
\hline $\begin{array}{l}\text { Penxedia } \\
\text { Property Reguler }\end{array}$ & - & Ada & Ada & Ada & Ada & Ada \\
\hline $\begin{array}{l}\text { Penxedia } \\
\text { Property } \\
\text { Premium }\end{array}$ & - & - & - & Ada & Ada & Ada \\
\hline Peers Consumers & & & & & & \\
\hline & $\begin{array}{l}\text { Pencari } \\
\text { Property/Pembeli } \\
\text { Property }\end{array}$ & Ada & Ada & Ada & Ada & Ada & Ada \\
\hline
\end{tabular}

\section{KESIMPULAN/RINGKASAN}

Kesimpulan yang didapatkan berdasarkan hasil penelitian tugas akhir ini adalah :

1. Dari pers pektif platform owners :

- Ditemukan bahwa mayoritas jenis perusahaan platform online property di Indonesia ialah Perseroan Terbatas

- Dapat disimpulkan bahwa mayoritas platform online property di Indonesia tedapat kepemilikian perusahaan luar negeri

- Meskipun telah beroperasi di Indonesia cukup lama, namun tidak menandakan bahwa banyak listing property yang ada pada suatu platform.

- Ditemukan bahwa usia beroperasi suatu platform tidak mengindikasikan platform tersebut menjadi pemain besar di Indonesia.

2. Dari pers pektif Stakeholder :

- Dapat disimpulkan bahwa, platform online property di Indonesia bersifat tertutup.

- Hampir seluruh platform online property di Indonesia, belum bergabung dengan asosiasi platform online, seperti ideA.

3. Dari pers pektif the partner :

- Hampir semua platform online property di Indonesia bekerjasama dengan bank, untuk memudahkan pengguna dalam pengajuan KPR.

- Seluruh platform online property di Indonesia bekerja sama dengan online news dan menyediakan artikel/blog/jurnal.
Tabel 5

\begin{tabular}{|c|c|c|c|c|c|c|}
\hline Grouping & \multicolumn{6}{|c|}{ Platform } \\
\hline Other Services & DP & RK & $\mathbf{R}$ & LI & Rl23 & $\mathrm{U}$ \\
\hline $\begin{array}{l}\text { Pencarian } \\
\text { Cepat }\end{array}$ & Ada & Ada & Ada & Ada & Ada & Ada \\
\hline Fayorit & Ada & Ada & Ada & Ada & Ada & Ada \\
\hline $\begin{array}{l}\text { History } \\
\text { Property }\end{array}$ & Ada & Ada & Ada & Ada & Ada & Ada \\
\hline $\begin{array}{l}\text { Kalkulator } \\
\text { KPR/Simulasi } \\
\text { KPR }\end{array}$ & Ada & Ada & Ada & Ada & Ada & Ada \\
\hline Acara & Ada & - & - & - & Ada & Ada \\
\hline Awards Events & Ada & - & - & - & - & - \\
\hline Blog/Artikel & Ada & Ada & Ada & Ada & Ada & Ada \\
\hline Feedback & Ada & Ada & Ada & Ada & Ada & Ada \\
\hline $\begin{array}{l}\text { Pengajuan KPR } \\
\text { Bary }\end{array}$ & - & Ada & - & Ada & Ada & Ada \\
\hline Panduan & - & Ada & Ada & Ada & Ada & Ada \\
\hline Bantuan & - & Ada & Ada & Ada & Ada & Ada \\
\hline $\begin{array}{l}\text { Cari melalui } \\
\text { Peta }\end{array}$ & - & - & Ada & - & Ada & Ada \\
\hline $\begin{array}{l}\text { Pencarian } \\
\text { dengan Iklan }\end{array}$ & - & - & Ada & - & - & Ada \\
\hline $\begin{array}{l}\text { Analisis } \\
\text { Property }\end{array}$ & - & - & - & - & - & Ada \\
\hline Komunitas & - & - & - & - & - & Ada \\
\hline FAQ & - & Ada & Ada & Ada & Ada & Ada \\
\hline
\end{tabular}

Tabel 6 Pemetaan The Transactions

\begin{tabular}{|c|c|c|c|c|c|c|}
\hline Grouping & \multicolumn{6}{|c|}{ Platform } \\
\hline Transaction & $\overline{\mathbb{R}}$ & LI & RK & R.123 & DP & $\overline{\mathrm{U}}$ \\
\hline $\begin{array}{l}\text { Meagiklankan } \\
\text { property secara } \\
\text { gratis }\end{array}$ & $\mathrm{Ad} \mathrm{a}$ & $\mathrm{Adz}$ & $\mathrm{Adz}$ & - & $\overline{A d a}$ & $\overline{\mathrm{Ad} 2}$ \\
\hline $\begin{array}{l}\text { Berikomuaikasi } \\
\text { denga Caloo } \\
\text { Pembeli }\end{array}$ & Ada & $\mathrm{Ad} \mathbf{2}$ & $\mathrm{Ad} \mathbf{a}$ & $\mathrm{Ad} z$ & $\mathrm{Ad} a$ & $\mathrm{Ada}$ \\
\hline $\begin{array}{l}\text { Melihat list } \\
\text { property yang } \\
\text { diiklankan }\end{array}$ & $\operatorname{Ad} z$ & $\mathrm{Ad} a$ & $\mathrm{Ad} 2$ & - & Ada & Ada \\
\hline $\begin{array}{l}\text { Menberikan } \\
\text { Feedhack }\end{array}$ & $\mathrm{Ad} 2$ & $\mathrm{Adz}$ & $\mathrm{Ad} 2$ & $\mathrm{Ad} 2$ & $\overline{\mathrm{Ad} z}$ & $\overline{\mathrm{Ad} z}$ \\
\hline Mescari Property & $\mathrm{Ad} \mathbf{z}$ & $\mathrm{Ad} 2$ & Ad2 & $\mathrm{Adz}$ & $\mathrm{Ada}$ & $\operatorname{Adz}$ \\
\hline $\begin{array}{l}\text { Menambah } \\
\text { Favorite }\end{array}$ & $\mathrm{Adz}$ & $\mathrm{Ad} 2$ & $\mathrm{Ad} 2$ & $\mathrm{Ad} \mathbf{A}$ & $\mathrm{Ad} 2$ & $\overline{\mathrm{Ad} z}$ \\
\hline $\begin{array}{l}\text { Melihat Histocy } \\
\text { Property }\end{array}$ & $\mathrm{Ad} 2$ & $\operatorname{Ada}$ & $\mathrm{Ad} 2$ & $\mathrm{Ada}$ & $\mathrm{Adz}$ & $\operatorname{Ada}$ \\
\hline $\begin{array}{l}\text { Bendiskesi } \\
\text { denga peagguna } \\
\text { lain }\end{array}$ & $\mathrm{Adz}$ & - & - & $\mathrm{Adz}$ & $\overline{\mathrm{Ad} a}$ & $\overline{A d} 2$ \\
\hline $\begin{array}{l}\text { Mengajukan } \\
\text { pertanyaan }\end{array}$ & $\mathrm{Ad} a$ & Ada & $\mathrm{Ad} \mathbf{2}$ & $\mathrm{Ad} 2$ & $\mathrm{Ada}$ & $\operatorname{Ad} 2$ \\
\hline $\begin{array}{l}\text { Melihat } \\
\text { Pertanyaan yang } \\
\text { scriag diajukaa }\end{array}$ & $\mathrm{Adz}$ & $\mathrm{Ad} \mathbf{z}$ & $\mathrm{Ad} \mathbf{z}$ & $\mathrm{Ada}$ & - & $\operatorname{Adz}$ \\
\hline $\begin{array}{l}\text { Membaca Artikel } \\
\text { Property }\end{array}$ & $\mathrm{Ad} \mathrm{A}$ & $\mathrm{Ad} \mathbf{2}$ & $\mathrm{Ad} \mathbf{2}$ & $\mathrm{Adz}$ & $\overline{\mathrm{Ad} 2}$ & $\overline{\mathrm{Ad} z}$ \\
\hline $\begin{array}{l}\text { Mencari talue } \\
\text { teatang property } \\
\text { terkini }\end{array}$ & $\mathrm{Ada}$ & $\mathrm{Adz}$ & $\mathrm{Ad} 2$ & $\mathrm{Ad} 2$ & Ada & - \\
\hline $\begin{array}{l}\text { Mengajukan } \\
\text { segala macam } \\
\text { KPR }\end{array}$ & - & $\mathrm{Ad} 2$ & $\mathrm{Ad} \mathbf{z}$ & $\mathrm{Ad} 2$ & - & $\mathrm{Ad} \mathbf{2}$ \\
\hline $\begin{array}{l}\text { Menghisung } \\
\text { angssura KPR }\end{array}$ & - & $\mathrm{Ad} \mathbf{2}$ & $\mathrm{Ada}$ & $\mathrm{Ad} 2$ & - & $\operatorname{Ad} 2$ \\
\hline $\begin{array}{l}\text { Mengetahui tips } \\
\text { and trick }\end{array}$ & - & $\mathrm{Ad} 2$ & $\mathrm{Ad} \mathbf{z}$ & $\mathrm{Ad} \mathbf{z}$ & $\mathrm{Ad} a$ & Ada \\
\hline $\begin{array}{l}\text { Meagevaluasi } \\
\text { Iklaz }\end{array}$ & - & - & $\mathrm{Ad} \mathbf{2}$ & - & Ada & $\overline{\mathrm{Ad} z}$ \\
\hline $\begin{array}{l}\text { Mengetahui } \\
\text { Acara teatang } \\
\text { Property }\end{array}$ & - & - & $\mathrm{Ad} 2$ & $\mathrm{Ad} 2$ & $\operatorname{Ada}$ & $\operatorname{Ad} 2$ \\
\hline $\begin{array}{l}\text { Membandiagkan } \\
\text { antar daa atau } \\
\text { kebih property }\end{array}$ & - & - & - & $\mathrm{Ad} \mathbf{z}$ & - & - \\
\hline $\begin{array}{l}\text { Mudah dalam } \\
\text { mencari property } \\
\text { internasional }\end{array}$ & $\mathrm{Adz}$ & - & - & $A_{12}$ & $\operatorname{Ad} \mathbf{z}$ & - \\
\hline $\begin{array}{l}\text { Mempromosilan } \\
\text { Profil }\end{array}$ & - & - & - & $\mathrm{Ad} \mathbf{2}$ & $\mathrm{Ad} 2$ & $\operatorname{Ad} 2$ \\
\hline $\begin{array}{l}\text { Mengetahui } \\
\text { lndeks Harga } \\
\text { Rumah }\end{array}$ & - & - & - & - & $\mathrm{Ad} 2$ & $\mathrm{Ada}$ \\
\hline
\end{tabular}

4. Dari perspektif the peers :

- Dapat disimpulkan bahwa semua platform online property di Indonesia memiliki peer producers yaitu agen corporate. 
- Rumah123 menjadi satu-satu nya platform online property di Indonesia yang menyediakan akun berbayar bagi pengguna peer producer-nya.

5. Dari persperktif services:

- Dapat disimpulkan bahwa mayoritas partner yang bergabung dengan platform online property, mendapat layanan yaitu link langsung ke website partner.

- Dapat disimpulkan bahwa mayoritas layanan yang diberikan kepada peers producers ialah dapat melihat daftar iklan property, kotak pesan, dan feedback.

- $\quad$ Dapat disimpulkan bahwa layanan yang pasti ada disetiap platform ialah pencarian cepat, favorit, history property, dan kalkulator KPR. Selain itu juga terdapat blog/artikel, feedback, dan FAQ.

6. Dari pers pektif transaction :

- Transaksi yang pasti dapat dilakukan oleh peers ialah berkomunikasi dengan pembeli/penjual, memberikan feedback, dan mencari property. Selain itu, juga dapat menambah favorit, melihat history property, dan membaca artikel tentang property.

7. Dari perspektif Channel and Context :

- Dapat disimpulkan bahwa mayoritas platform online property memberikan Dashboard untuk memudahkan pengguna.

8. Dari perspektif Infrastucture and core component:

- Dapat disimpulkan bahwa mayoritas platform online property sudah meyediakan mobile application.
9. Dari perspektif Value proposition :

Core value target yang diciptakan platform berbedabeda. Platform yang menargetkan value nya pada peer consumers ialah UrbanIndo, Lamudi Indonesia, dan dotProperty. Platform yang menargetkan value nya pada peer producers, ialah rumahku.

\section{DAFTAR PUSTAKA}

[1] B. Koordinasi, P. Modal, and R. Indonesia, "Realisasi Penanaman Modal Pmdn - Pma," no. April, 2016.

[2] C. Quarterly, "Jakarta property market report," no. April, 2017.

[3] S. Kemps, "Digital In 2017: Global Overview," We Are Social, 2017. [Online]. Available: ttps://wearesocial.com/sg/blog/2017/01/digital-in-2017global-overview. [Accessed: 26-Sep-2017].

[4] S. Hu and Q. Li, "Modeling and simulating a smart information-based real estate online platform," Procedia Comput. Sci., vol. 111, no. 2015, pp. 339-347, 2017.

[5] S. Cicero, The User Guide : Platform Design Toolkit. 2009.

[6] M. Boncheck and S. Paul Choudary, "Three Elements of a Successful Platform Strategy," 2013. [Online]. Available: https://hbr.org/2013/01/three-elements-of-asuccessfulplatform. [Accessed: 26-Sep-2017].

[7] J. Hagel, "Edge Perspectives with John Hagel: Platforms Are Not Created Equal: Harnessing the Full Potential of Platforms," 2014. [Online]. Available: http://edgeperspectives.typepad.com/edge_perspectives\% $0 \mathrm{~A} /$ 2014/08/platforms-are-not-created-equal-harnessingthe-fullpotential-of-platforms.html. [Accessed: 27-Sep-2017]. 